\title{
Quviasukvik. The celebration of an Inuit winter feast in the central Arctic
}

Frédéric Laugrand and Jarich Oosten

\section{(2) OpenEdition \\ Journals}

Electronic version

URL: http://journals.openedition.org/jsa/2772

DOI: 10.4000/jsa.2772

ISSN: 1957-7842

Publisher

Société des américanistes

\section{Printed version}

Date of publication: 1 January 2002

Number of pages: 203-225

ISSN: 0037-9174

\section{Electronic reference}

Frédéric Laugrand and Jarich Oosten, «Quviasukvik. The celebration of an Inuit winter feast in the central Arctic », Journal de la Société des américanistes [Online], 88 | 2002, Online since 05 January 2007, connection on 10 December 2020. URL : http://journals.openedition.org/jsa/2772 ; DOI : https:// doi.org/10.4000/jsa.2772 


\title{
QUVIASUKVIK \\ THE CELEBRATION OF AN INUIT WINTER FEAST IN THE CENTRAL ARCTIC ${ }^{1}$
}

\author{
Frédéric LAUGRAND * and Jarich OOSTEN **
}

In this paper we discuss the celebration of Christmas among the Inuit of Northeast Canada. Their adoption of Christianity implied a break with the past. Missionaries as well as Inuit contrasted the traditional life dominated by many ritual rules, with the new Christian life. In practice, the transition was much more complex. Many old ideas and practices did not die as easily as missionaries or Inuit assumed, but returned in a new guise. Using White and Inuit testimonies, we examine here the nature of this transition by comparing the pre-Christian Inuit winter-feasts with the celebration of Christmas after the conversion to Christianity. Many features of the pre-Christian religion returned in the Christmas celebrations but in a new context and provided with new meanings. We have considered temporal and regional variation as well as the differences between the Catholic and Anglican versions of the feast. Central topics are : gifts, food and drinks, games and sexual symbolism.

KEy words : Inuit, Christmas, Winter-feast, Tirajuut, ritual, symbolic system, ethnohistory, Canada.

\section{Quviasukvik : la célébration d'une fête hivernale inuit dans l'Arctique central}

Dans cet article, nous examinons les fètes de Noël chez les Inuit de l'Arctique de l'Est canadien. L'adoption du christianisme par les Inuit s'est traduite par d'importantes ruptures avec le passé. Comme les missionnaires, les Inuit eux-mêmes ont souvent souligné le contraste entre les multiples contraintes rituelles de la vie religieuse de jadis et la plus grande liberté que leur procurait dorénavant le christianisme. Au niveau des pratiques, la transition d'un système à l'autre fut néanmoins beaucoup plus complexe. Loin de disparaître, certaines idées et séquences rituelles réapparurent de façon sensiblement différente. À partir de témoignages recueillis par des Blancs et des Inuit, nous analysons de plus près la nature de cette transition en comparant les fêtes d'hiver traditionnelles avec les fêtes de Noël. Des éléments traditionnels connurent une certaine pérennité mais au sein de nouveaux contextes et avec de nouvelles significations. Nous avons tenu compte des variations temporelles, régionales et confessionnelles. Les principaux aspects examinés sont les cadeaux, la nourriture, les boissons, les jeux et la symbolique sexuelle.

Mots ClÉs : Inuit, Noël, fètes d'hiver, Tivajuut, rituel, systèmes symboliques, ethnohistoire, Canada.

* Université Laval, Ste-Foy, GIK 7P4, Québec, Canada.

** Universiteit Leiden, P.O.B. 9515, 2300 RA Leiden, Holland.

Journal de la Société des Américanistes, 2002, 88 : p. 203 à 225. Copyright @ Société des Américanistes. 


\section{Quviasukvik : la celebración de una fiesta invernal de los imuit del este de Canadá}

En este artículo, se analizan las fiestas de Navidad de los inuit del este de Canadá. La conversión al cristianismo de los inuit implicó una ruptura mayor en sus tradiciones. Como los misioneros, los inuit frecuentemente contrastan la nueva situación religiosa con la precedente, caracterizada por sus numerosas reglas e interdicciones rituales. Sin embargo, al nivel de las prácticas, esta transición de un sistema al otro parece mucho más compleja. En lugar de desaparecer totalmente, algunas ideas y prácticas rituales reaparecieron de una manera más o menos distinta. Utilizando narraciones de testigos occidentales e inuit, analizamos en detalle esta transición. Comparamos las fiestas invernales de los inuit con las fiestas contemporáneas de la Navidad. En este caso se destaca rupturas y continuidades dentro de nuevos contextos festivos. Tomamos en cuenta las variaciones temporales, regionales y confesionales. Elementos considerados incluyen los regalos, los alimentos, las bebidas, los juegos y el simbolismo sexual.

Palabras claves : Inuit, Navidad, fiestas del invierno, Tivajuut, rito, sistemas simbólicos, etnohistoria, Canadá.

Quviasukvik, "the time and/or place of joy ", is rooted in Western as well as in Inuit traditions. In contemporary Western societies, Christmas is part of a complex cycle in the Christian liturgical calendar celebrated in the church, at home or in the community at large. The traditions of the Church and those of popular religion usually co-exist and interact. They may also clash and this may even lead to attempts to repress supposedly non-Christian dimensions of Christianity as illustrated by D. Miller (1993). The burning of an effigy of Santa Claus in Lyon by two bishops in 1951, described by C. Lévi-Strauss (1952), evoked a pagan ritual and illustrated the complexity of the separation of Christian and non Christian elements in the EuroAmerican tradition.

The complexity of modern Christmas celebrations should be seen in a historical perspective $^{2}$. In the early Christian Church, Easter, not Christmas, was the most important religious feast. Christmas celebrations only gained importance in the $4^{\text {th }}$ century AD. The Roman Church adopted the date of December 25, celebrated by the Romans as the winter solstice. The choice expresses the close connection between Christ and the sun in early Christian religion. Christ rapidly adopted striking features of the sun god Helios such as the halo. The resurrection of Christ took place on a Sunday, the day that replaced the Jewish Sabbath as a day of religious observation and celebration. In the Roman empire the celebration of Christmas replaced the feast of Sol Invictus, the rebirth of the sun at December 25 .

The liturgical Christian calendar developed in accordance with pre-Christian practices. In Celtic religion the year was divided into Beltaine and Samuin. Samuin began at November $1^{\text {st }}$. Then the dead roamed about and a period of intensive ritual activity started that ended after the winter solstice. The Christian calendar followed a similar pattern. The period from November 1 (All Saints) until the beginning of January (Epiphany) is a period of intensive ritual activity. It is characterized by various features such as masquerades, gift giving, extinguishing and re-lighting of lamps, etc. These features emerge in various combinations in festivities such as Santa Claus and Epiphany. Many studies have been devoted to these rituals and their 
interpretation. Thus C. Lévi-Strauss argues that while receiving presents from Santa Claus the children represent the dead. Santa Claus himself is a complex figure, combining the features of a saint with those of the devil. In some parts of Germany and Austria, Santa Claus was a member of bands of masked figures, sometimes with black faces and chains, roaming the streets, terrorizing the women. They were wearing attributes of devils and associated with death as well as sexual ribaldry. Santa Claus was introduced in North America by the Dutch in the seventeenth century. At that period, the feast of Santa Claus was celebrated as feast of children and youngsters. The sexual overtones of the feast were obvious. The ambiguous behavior of Santa Claus was adopted in America when the Dutch and German Santa Claus traditions were integrated into American culture. The sexual connotations were suppressed in most places, but often preserved in songs and attributes of Santa Claus.

When studying the impact of Christmas on Inuit society we have to take into account that Euro-American celebrations contained a wide variety of traditions dealing not only with the birth of Christ, but also with the winter solstice, the visit of the dead, gifts to children, and sexual symbolism. These features are often deeply rooted in Euro-American traditions of Christmas and sometimes combined. Still, considerable regional variety existed in the use of specific symbols such as Santa Claus, the Christmas tree, choice of foods and other characteristic features of celebrations in Northwest Europe and North America. While on the whaling ships ambiguous songs and dances were part of the Christmas celebrations, missionaries later emphasized the religious aspects of the feast. All these elements had an impact on Inuit celebrations of Christmas, but they were not valorized by the participants in the same way. Moral discussions on how Christmas should be celebrated always were part of the feast. In the development of Quviasukvik strands from Inuit traditions and Western traditions merged. We explore some of the principles and values in the transformation of these different traditions.

\section{« TraditionaL » INUIT IVINTER FEASTS}

The Inuit winter feasts were celebrated in the fall or the early winter. Various descriptions or (parts of) these winter-feasts exist in the ethnography.

C. F. Hall $(1864,1$, p. 528) provides one of the earliest accounts of the feast as celebrated by the Nugumiut in South Baffin Island :

At a time of the year apparently answering to our Christmas, they have a general meeting in a large igdlu [snow house] on a certain evening. There the angakoq [the shaman] prays on behalf of the people for the public prosperity through the subsequent year. Then follows something like feast. The next day all go out into the open air and form in a circle ; in the centre is placed a vessel of water, and each member of the company brings a piece of meat, the kind being immaterial. The circle being formed, each person eats his or her meat in silence, thinking of Sedna, and wishing for good things. Then one in the circle takes a cup, dips up some of the water, all the time thinking of Sedna, and drinks it ; and then, before passing the cup to another, states audibly the time and the place of his or her birth. This ceremony is performed by all in succession. Finally, presents of various articles are thrown from one another, with the idea that each will receive of Sedna good things in proportion to the liberality here shown. Soon after this occasion, at a time which answers to our New Year's day, two men start out, one of them being 
dressed to represent a woman, and go to every house in the village, blowing out the light in each. The lights are afterwards rekindled from a fresh fire. When Taqulitu was asked the meaning of this, she replied, « New sun-new light », implying a belief that the sun was at that time renewed for the year.

In this brief description we find many elements that return in later descriptions of Inuit winter feasts and Christmas celebrations. According to Hall, this feast comprises one evening and the next day. The evening is marked by the activities of the angakkuit (the shamans), praying on behalf of the community. The next day the focus shifts from the actions of the angakkuit to the feast of the community at large. Meat and drinks are shared by all participants. Each one has to bring a piece of meat. Whereas the meat seems to be consumed simultaneously, each individual concentrating on Sedna (the imua or owner of the sea game), the water seems to be consumed in succession by all participants, but the order is not indicated. Each one in turn specifies time and place of birth. The time of birth refers to summer or winter indicating whether one belongs to the ducks (or the summer people) or the ptarmigans (or winter people). Then presents are exchanged. The liberality shown is reciprocated by Sedna. Subsequently the lights are extinguished by two men dressed up as women visiting all the houses. Finally the lamps are rekindled from a fresh fire. It is not specified by whom the fire is rekindled or how the fresh fire is made. The explanation by Taqulitu suggests a close relationship between the new sun and the new light.

A much more extensive description of an Inuit winter-feast is given by Franz Boas ([1888] 1964, pp. 195 ff.). F. Boas witnessed it in Qiqirtat (Kekerten Island), Cumberland Sound, on November 10, 1883. The feast was celebrated late in the fall. The tupilait, the spirits of the dead, who did not arrive at their final destiny in the land of the dead, attacked the community, people as well as dogs. These evil spirits brought sickness, death and bad weather. The angakkuit were intensively performing their practices inside the house to protect the people. In a large hut the ritual of harpooning Sedna, was conducted by the angakkuit. She was lured up by a magic song and harpooned with a seal spear. She freed herself from the harpoon and descended to the underworld again. The angakkuit showed the blood-sprinkled harpoon to the audience. The next day a great festival for young and old was celebrated. All wore protective amulets (such as the garments they wore after birth) to protect themselves against Sedna who was still enraged. Then :

The men assemble early in the morning in the middle of the settlement. As soon as they have all got together they run screaming and jumping around the houses, following the course of the sun (nunajisartung or kaivitijung). A few, dressed in women's jackets, run in the opposite direction. These are those who were born in abnormal presentations. The circuit made, they visit every hut, and the woman of the house must always be in waiting for them. When she hears the noise of the band she comes out and throws a dish containing little gifts of meat, ivory trinkets, and articles of sealskin into the yelling crowd, of which each one helps himself to what he can get. No hut is omitted in this round (irqatatung).

The crowd next divides itself into two parties, the ptarmigans (axigirn), those who were born in the winter, and the ducks (aggirn), the children of the summer. A large rope of sealskin is stretched out. One party takes one end of it and tries with all its might to drag the opposite party over to its side. The others hold fast to the rope and try as hard to make ground for themselves. If the ptarmigans give way the summer has won the game and fine weather may be expected to prevail through the winter (nussueraqtung). 
The contest of the seasons having been decided, the women bring out of a hut a large kettle of water and each person takes his drinking cup. They all stand as near to the kettle as possible, while the oldest man among them steps out first. He dips a cup of water from the vessel, sprinkles a few drops on the ground, turns his face toward the home of his youth, and tells his name and the place of his birth (oxsoaxsavepunga - me, I was born in -). He is followed by an aged woman, who announces her name and home, and then all the others do the same, down to the young children, who are represented by their mothers. Only the parents of children born during the last year are forbidden to partake in this ceremony. As the words of the old are listened to respectfully, so those of the distinguished hunters are received with demonstrative applause and those of the others with varying degrees of attention, in some cases even with joking and raillery (imitijung).

Now arises a cry of surprise and all eyes are turned toward a hut out of which stalk two gigantic figures. They wear heavy boots ; their legs are swelled out to a wonderful thickness with several pairs of breeches; the shoulders of each are covered by a woman's overjacket and the faces by tattooed masks of sealskins. In the right hand each carries the seal spear, on the back of each is an inflated buoy of sealskin, and in the left hand the scraper. Silently, with long strides, the qailertetang (figure 146) approach the assembly, who, screaming, press back from them. The pair solemnly leads the men to a suitable spot and set them in a row, and the women in another opposite them. They match the men and women in pairs and these pairs run, pursued by the qailertetang, to the hut of the woman, where they are for the following day and night man and wife (mulianititijung). Having performed this duty, the qailertetang stride down to the shore and invoke the good north wind, which brings fair weather, while they warn off the unfavourable south wind.

As soon as the incantation is over, all the men attack the qailertetang with great noise. They act as if they had weapons in their hands and would kill both spirits. One pretends to probe them with a spear, another to stab them with a knife, one to cut off their arms and legs, another to beat them unmercifully on the head. The buoys which they carry on their backs are ripped open and collapse and soon they both lie as if dead beside their broken weapons (pilekting). The eskimo leave them to get their drinking cups and the qailertetang awake to new life. Each man fills his sealskin with water, passes a cup to them and inquires about the future, about the fortunes of the hunt and the events of life. The qailertetang answer in murmurs which the questioner must interpret for himself. The evening is spent in playing ball, which is whipped all around the settlement (ajuktaqtung) (see Appendix. Note 6) (Boas [1888] 1964, pp. 195-198).

This description of the winter-feast provided by Boas ([1888] 1964) in his first monography differs on some points significantly from the data collected in his field notebook as published by L. Müller-Wille (1998). Thus the reference to the fact that the men running around the settlement in the early morning wear their best pants is not retained in the 1888 description. Various details that suggest direct influence or contact with the whalers are also omitted. For instance, in his notebook Boas relates that the men visited the house of Captain Mutch and the cooper. In his diary, Boas notes that after the public statements relating to the origins and the names of the participants, " a snowman with coal for eyes was built down below and the men shot at it " (Müller-Wille 1998, p. 137) and he no longer refers to his own intervention as he threw out beads among the people resulting in a fine struggle for the beads (ibid. p. 138). It seems that Boas was intent on describing the winter-feast as a " traditional Inuit feast » and did not want to distort that picture by unnecessary references to Western influences or participation. However, some of the features omitted such as the use of best clothes and the shooting became important features of later Christmas celebrations. 
Moreover, it may well be that a crucial stage of the ritual, the harpooning of Sedna on the eve of the feast, is entirely based on reconstruction, as no reference is made to it in the notebook in the entries on November 10 and November 11. Apparently, Boas spent the night of November 10 to 11 reading three books.

Despite these reservations the description of the feast by Boas still provides the most detailed and instructive account of the feast available ${ }^{3}$.

At the beginning of the winter feast, the evil spirits of the dead attack the communities. The exchange of violence between the spirits of the deceased and the Inuit is gradually replaced by friendly competition and a sharing of women and goods by members of the community representing the dead. At the end of the feast, the members of the community play the ajuktaqtung game that is also played by the Ullormiut, the people of the day, the souls of the deceased in the sky. The Ullormiut are thought to have a happy life, in contrast with the tupilait, the spirits of the dead, that cannot find rest.

The antagonistic relationship between the evil spirits of the dead and the Inuit is gradually transformed into a positive relationship between the Inuit and their deceased ancestors allowing them to represent the people of the day in play ${ }^{4}$.

In the course of the ritual the success of the hunt is assessed in various divinatory games such as the tug-of-war of the ptarmigans and the ducks. Thus we may infer from the structure of the ritual that the relationship to the spirits of the dead is decisive in determining the success of the hunt. It is remarkable that the animals themselves never are partners in the ritual interactions between the Inuit with either the spirits of the dead or Sedna and her representatives, the qailertetang.

The sexual intercourse between men and women plays an important part in the ritual. Its meaning remains implicit, but it is also a recurrent feature of the Inuit winter feasts in the North Baffin area, the Tivajuut ${ }^{5}$. More generally, it is a striking feature of ritual exchange in Inuit communities that directly drew the attention of the missionaries and became one of the main issues of controversy. Apparently this sexual intercourse was thought to favor the hunting of game. The exchanges in the feast as described by Boas concern small gifts such as « meat, ivory trinkets, and articles of sealskin into the yelling crowd, of which each one helps himself to what he can get. No hut is omitted in this round (irqatatung). " These distributions resulted in a general competition (scramble) for the goods. The distribution of Boas' own beads follows the same pattern. The distribution of the women is quite another matter. It is regulated by the intervention of the representatives of the spirits who organize the adults into pairs.

A ritual form of drinking occurred during the feast relating the Inuit to their origins. Exchange of food seems to play a role of minor importance in the feast. In her description of the Tivajuut, the late Rose Iqallijuq, referred to an abundance of food after the feast as it was celebrated in Iglulik, North Baffin Island. When the Aagjuuk stars began to return in the middle of the December ${ }^{6}$, the Tivajuut was celebrated in the qaggiq, a big igloo specially built for a feast. According to George Agiaq Kappianaq, an elder from Iglulik, the celebration was made to strengthen the land (MacDonald 1998, p. 40). There is no reference to Sedna or the inua of the sea in his descriptions of the feast. The contest between the aggiqiq (ptarmigans) and aggiarjuit (ducks) played an important part in the feast (MacDonald 1998, pp. 120-123). A central part of the ritual was the formation of couples that had to sleep together. This 
was done by two masked angakkuit. When the pairs were formed, the other participants in the feast tried to make them laugh, but the pairs had to restrain themselves. According to Rasmussen (1929, pp. 231-232 ; pp. 241-243), the feast was followed by a copulous meal of igunaq (aged walrus meat). In his paper, B. Saladin d'Anglure (1989, p. 165, footnote 29) points out that the distribution of women by the two masked angakkuit was referred by the same term as the distribution of frozen meat, ikujijut. The woman was referred to as an ikuktaq, a part separated from a whole by a violent act.

The dating of the feast is unclear and may have varied in different areas. Hall connects it to Christmas. In Arctic Bay, C. Trott (oral com., 17-08-1998) recorded a song referring to the rising of Akkuktujut (Orion's shoulder stars). He was told by Inuit that in the darkest period when both the sun and the moon were below the horizon, the rising of this star told the Inuit that daylight was about to return, and was thus an occasion for celebration. More recently, George Kappianaq from Iglulik connected the feast to the appearance of the Aagjuuk. Thus the Tivajuut seems to have been celebrated in December. Boas witnessed a winter feast on November 10, 1883. Bilby (1923, p. 210) connects the feast to the tempestuous weather following the Arctic summer: Thus the feast was celebrated much earlier than December in South Baffin Land. Apparently the feast was not connected to the winter solstice, but prepared the hunting of the winter season.

\section{INUIT WINTER FEASTS AND CHRISTMAS}

European and American Christmas traditions may already have played a part in the shaping of the Inuit winter feasts in the $19^{\text {th }}$ century ${ }^{7}$. Inuit had often the opportunity to witness celebrations of Christmas on the ships of explorers and whalers. In 1860, several Inuit witnessed Christmas on Hall's ship. He gave a Bible to Tookoolito who had spent two years in England :

Among the other incidents to be mentioned [...] I must not forget to say that Christmas and New Year's Day were celebrated by us in our winter quarters with all the honours it was in our power to show. A few of the natives were on board to dine on Christmas Day, and I took the opportunity to give Tookoolitoo a Bible that had been placed in my hands by the Young men Christian's Union of Cincinnati, and which I thought could not be devoted to a better purpose. I inscribed upon it the following: "Presented to Tookoolito, Tuesday, December 25th, 1860 ». "Her first act was to read the title, "Holy Bible", then to try and read some of its pages, which she still longs to understand. » (Hall 1864, p. 193)

Hall and Boas both record that in the winter feasts everyone received a drink of water and then solemnly pronounced his name and place of origin. This type of ritual may have been inspired by European traditions of drinking to the health of important people and friends in the homeland at Christmas that were also practiced on European ships ${ }^{8}$.

Alcoholic beverages, abundant food and even cross-dressing may have been recurrent features of Christmas celebrations on board of the ships. Lyon (1824; quoted in Harper 1983, p. 2) described a Christmas celebration in 1821 : 
On Christmas Eve, in order to keep the people quite and sober, we performed two farces, and exhibited phantasmagoria so that the night passed merrily. Christmas Day was very fine, and we all attended church on board the Fury as we had been accustomed to do every Sunday since we were frozen in. The people then returned to their dinners at which English roast beef, that had been kept untainted since the transport left us, was the principal luxury. To these were added cranberry pies and puddings of every shape and size, with full allowance of spirits. I never indeed saw more general good humour and merriment on a Christmas day since I went to sea. A pretty compliment was paid to all the oflicers by a well meaning, but certainly not very sober crew, by absolutely forcing each in his turn, beginning with myself, to go out on the lower deck and have his health drank with three hearty cheers.

On the $26^{\text {th }}$, we sent all the people for a run on the ice, in order to put them to rights, but thick weather coming on, it became necessary to recall them, and, postponing the dinner hour, they were all danced sober by 1 PM, the fiddler being, fortunately, quite as he should be. During this curious ball, a witty fellow attended as an old cake woman, with lumps of frozen snow in a bucket ; and such was the demand for his pies on this occasion, that he was obliged to replenish pretty frequently.

Each of the officers, in hierarchical order starting with the captain received a toast. Even though the celebrations at the ships of Parry and Lyon were not witnessed by Inuit, similar celebrations on whaling ships or other visiting ships may have been observed by Inuit in some areas of Northeast Canada. Was the custom of drinking in turn, following a hierarchical order; observed by the Inuit and integrated into their own rituals ? We do not know. But a hundred years earlier, Egede noted with respect to the Greenlanders : « When they come at a water from which they have not drunken before, an old man, if they have one with them, should drink first, in order to isolate the Tornarssuk, that is the evil in the water that would make the young men ill and die " (Egede 1986, pp. 383-384). The importance of first acts in Inuit culture is well attested, and it seems to be the task of the old men to mediate the drinking of water. The drinking of water in hierarchical order as described by Boas may well be an old Inuit custom.

Similarly the cross-dressing on the ships at Christmas may have influenced Inuit rituals. But cross-dressing also played an important part in the winter feasts in Greenland and it was part of the naming system in the Northeast Canada. Children named after someone of the opposite sex might be dressed and raised according to the gender of their deceased namesakes. In various Studies of Christmas celebrations in Labrador(Ben-Dor 1969 ; Richling 1983 ; Szala-Meneok 1994) masquerading rituals were attributed to Western influence, but in fact, we have far too little data ${ }^{9}$. Just as in the case of the drinking rituals, ethnographic data from another area may easily change our views. In this paper we avoid the dangerous question of origins, Western or Inuit, but focus on the emergence of new forms of rituals combining features of different cultural traditions. We will examine celebrations of Christmas in Northeast Canada, notably the Baflin Island area between 1890 and 1960. We will first consider testimonies from Qallunaat observers (White men) and then those of Inuit elders.

\section{Christmas celebration 1894-1930s}

As soon as the missionaries opened a permanent mission in Baffin Island (1894), they instituted the celebration of Christmas. Reverend E. J. Peck recorded brief descriptions of these celebrations in his diary. 
Had quite a number of our Eskimo friends along today. Several brought presents of gloves, caps, etc., which they had knitted, and some of which they desired us to use for our own comfort, and also to show to the kind ladies in England who had sent them the wool, and knitting pins. After friendly greetings, we entertained our visitors with coffee and cake, and pointed out to them the true reason why we should rejoice on this day. [...] The great events of the season, viz. distribution of prizes and illumination of Christmas tree, the latter made by Mr. Parker, proved a great success. [...] After singing a hymn and engaging in prayer the distribution of prizes took place. These were, first for the most regular attendants at school, second, for the most cleanly. One girl who had not missed a day at school, received the first prize, another girl had only missed one, while another had only been absent twice. Fourteen prizes were given to those who had shown some love, at least for soaps and water, and had made their appearance at school with clean faces and hands. [...] After distribution of prizes, [...] each member of our little flock was presented with some article (ANC/CMS, Reel A. 119, Journal from E. J. Peck, 1895-1896, 24-12-1895).

Peck thought the giving of prizes and the illumination of the Christmas tree were the highlights of the day. The Inuit arrived with gifts, some of them intended for the English ladies who had sent gifts to them. Conversely, at the end of the feast all the members of the flock received gifts from the missionaries. They provided the Inuit with food and drink and used the opportunity to preach the gospel. That became a tradition in Uumanarjuaq (Blacklead Island, Cumberland Sound). Each Christmas the missionaries provided Western style food and drinks and awarded prizes for past performances. In 1895, the prizes were given for school attendance, two years later for ability to memorize the scriptures. Thus the aspect of competition, so essential to Inuit feasting, was preserved in the Christmas celebrations. In contrast, the Christmas tree did not gain an important place in Inuit Christmas celebrations for a long time.

Christmas celebrations organized by the missionaries continued to follow this pattern after Peck left ${ }^{10}$. Special food was provided by the missionaries for the Inuit and the opportunity was used to teach the Inuit some of the Christian values. A small gift was also provided with a reminder of God's Great Gift to humankind (see Fleming's description of a Christmas celebration in 1913 published by Harper (1983, pp. 17-18). Among the Oblate, similar traditions can be found. L. Ducharme notes that in Igluligaarjuk (Chesterfield Inlet), the first Catholic mission in Hudson's Bay opened in 1912, Christmas was the most joyful time of the year. Peoples would come from afar. Besides the big meal, missionaries and Grey Nuns used to organize a fishing party with all kinds of small gifs : clothes, biscuits, candies, tobacco, pipes, matches, dolls, etc. ${ }^{11}$

Christmas celebrations were also organized on visiting ships. An early $20^{\text {th }}$ century description by Captain J. E. Bernier shows how Inuit were invited on his ship in North Baflin Island and participated in the European celebrations of Christmas in 1906.

On December 24 the ship was washed and cleaned and the officers had their state rooms decorated for Christmas with flags and family photos.

Our native Kanaka was instructed to tell the other natives that they were invited to spend Christmas day on board with their families. I gave orders to the steward to have dinner ready for about one hundred natives. Preparations were made to receive them ; I also sent an invitation to Captain Mutch to celebrate Christmas with us.

December $25^{\text {th }}$, Christmas Day - There was Sunday service in the forenoon ; it was well attended by the members of the expedition and some of the natives who had already arrived for the dinner. At 1 P.M. all the natives had arrived on board with their families; about one hundred 
and twenty persons, they sat down to a good Canadian dinner. After dinner I addressed them a few words ; telling them again that they were Canadians and would be treated as such as long as they would do what was right. At 7 P.M. tea and coffee were served to all the invited, and some candy was given to the children. A deputation of natives and some members of the crew came and asked my permission to dance on board. Knowing the pleasure it would afford them, I could not refuse the request and was glad to accede to their wishes and see that they would amuse themselves. The natives behaved very well and there were no disturbances of any sort, but perfect good order reigned throughout. During the evening there were different tricks and acts done by the members of the expedition and natives. There were wrestling matches between Canadians and other matches of the same style between Eskimos; the men also performed acrobatic feats, juggling and other acts. Music selections from the pianola and the gramophone were given during the evening. The Eskimos danced to the music of the accordion. It was well on to twelve o'clock before the dance ceased and the natives left for their homes. Everybody seemed to have enjoyed himself immensely and was glad of the celebration.

The Christmas celebration is described as a Canadian banquet to which Inuit are invited. Small gifts were often added (see also accounts given by Captain H. T. Munn 1932, p. 252). On the ship of Bernier the element of dancing is added on the request of the natives and members of the crew. The first missionaries also used a gramophone to provide music, but there are no references to dancing in the celebrations they organized. A striking feature of all performances is how Canadians and Eskimos joined in competitive games. Feasting the Inuit on food was also a recurrent feature of Christmas celebrations organized by Qallunaat (see also the description of Christmas 1910 : Arctic Bay, Baffin Island by J.-E. Bernier in 1909, quoted in Harper 1983, p. 12).

\section{Christmas celebrations in the twenties and thirties}

In the twenties and thirties, after many Inuit had already been converted in South Baffin Island, Christianity was also adopted by most of the Inuit in the North Baffin area. Conversions often took place before missionaries arrived : Bibles and Hymn books distributed by the Anglican missionaries had reached North Baflin Island, and Inuit leaders were acting as fervent Christian proselytes. New rituals such as the siqqitirniq (Laugrand 1997) were developed and various parousial movements combining Christian and shamanic features came up in the area (Blaisel, Laugrand \& Oosten 1999). In the early thirties, missionaries opened missions in Mittimatalik (1929), Iglulik (1931, but officially founded in 1933), and Pelly Bay (1935). Missionaries as well as traders contributed extensively to the development of the Christmas celebrations $^{12}$.

Richard Finnie (Harper 1983, pp. 36-39) described his memories of Christmas celebrations at the trading post of Coppermine 1930. The missions and the store took care they had sufficient supplies for that event. By the $24^{\text {th }}$ almost one hundred and forty Inuit had assembled at the settlement. After building their igloos the Inuit " started according to a custom they had developed to go the rounds of all the white men's dwellings, staying at each one long enough to enjoy some refreshments, mainly hardtack and tea. " At Christmas day the trading post apprentice paraded outside as Santa Claus. The impersonation lasted only for a few minutes. His beard soon fell of and he was recognized. Then he handed out gifts to the children. Later the white 
people danced with the Eskimo women to the latest Broadway tune. At five o'clock a dinner was organized at the wireless station. After dimner the Qallunaat heard that a native dance was performed and joined the Inuit in an enormous igloo where a drum dance was performed for several hours.

The feast was an occasion for intensive interaction between Inuit and Qallunaat. Qallunaat hosted Inuit who came to the houses to receive treats, but also became guests of the Inuit witnessing the dancing and feasting in the great igloo. The great igloo clearly had the function of the traditional feast house (qaggiq) where the great winter feasts used to be celebrated. Whereas Qallunaat and Inuit danced together at a party given by the doctor, Qallunaat did not participate in the drum dances and the songs of the Inuit. The impersonation of Santa Claus is unusual. Only much later he became an important figure in Christmas celebrations.

In 1935 in Mittimatalik (Pond Inlet, North Baflin Island) a similar pattern emerges from an account of Christmas provided by Alex Stevenson (Harper 1983, pp. 2628). Several days before Christmas, the Hudson's Bay Company store turned baking supplies over to several Eskimo women so that preparations could be made for Christmas dinner. On Christmas Day the Inuit moved into the warehouse for the feast. A special dinner was prepared for the guests (the two police men and the missionaries). After dinner races and games were held, notably dog team races. In the evening a dance party was organized accompanied by accordion and fiddle : « Although the old Eskimo drum dances were still held in some Arctic settlements, the people of Pond Inlet preferred reels and jigs from the early Scottish whalers. » (ibid. p. 28)

Qallunaat testimonies indicate that they played a central part in the organization of the Christmas celebrations. They provided the Inuit with the means to celebrate Christmas. Qallunaat influences manifested themselves in many ways : food, clothing, dances, etc. Thus traditional Inuit dances were giving away to new forms of dancing introduced by the Whites. In their descriptions the main emphasis is on food and the topics of games, music and dancing. Little attention is given to the gift exchange between the Inuit. On the contrary, in Inuit testimonies referring to the same period the gifts have a central place. These testimonies provide a much better understanding of the ways Christmas was celebrated by the Inuit.

\section{TESTIMONIES OF INUIT ELDERS}

Inuit elders have vivid memories of the Christmas celebrations in their youth. Obviously these celebrations can not be dated precisely. Most recollections by elders probably refer to the thirties and early forties. In the following section, we first present a few of their narratives taking into account regional variation as well as various differences and similarities between Catholics and Anglicans. Then we illustrate the merging of Inuit and Christian traditions in the celebration of Christmas with an account provided by a white observer from Arviligjuaq (Pelly Bay).

Emile Imaruittuq, about 68 years of age, remembers his first Christmas in the Iglulik area (North Baffin Island). Games were organized by the Oblate missionary.

While the light was briefly on the priest would have a line tied to the string. He used to shoot at the string and that was the game. There would be three chances to cut this little string with a 
bullet. Whoever shoots the string would have the prize. It was just a 22 gun that would be used. In the olden days when I started remembering, we used to exchange gifts, we actually would give to ourselves. Even to the standard it was not much, in those days it was very precious. That is how we used to give each other. As the years went by, that giving and receiving attitude start disappearing. The whole feeling of Christmas has more and more faded away. To our grandchildren we still give when we are able, when we have the money. In the olden days we also used to have a feast. It was the Roman Catholics that introduced to us the celebration of Christmas. First, we would go to the service and in the same place we would have a feast : pilot biscuits, beans, etc. We used to make beans and that was part of the feast. It used to be so delicious ! In the olden days they started celebrating Christmas as well within the homes, eating country food. [...] My grandmother would take out flour and make pancakes during Christmas. That was very special. Many elders and adults used to save special food, special diet, for Christmas and that's how it was in the Iglulik area.

In Imaruittuq's account the games organized by the priest, the gifts, and the food have a central place. The game he refers to was often played at Christmas. Country food as well as Western style food were also frequently used according to the elders. The act of giving is emphasized. The gifts might be small, it was the act of giving that counted.

Michel Kupaaq, an elder from Iglulik, related that the gift might even be completely symbolic :

People would gather for the feast. In the Christmas time (Quviasukvik), people would go to church for the midnight mass. But after twelve hours, we would go back to the church. Nowadays, Christmas is longer. We play games all the week long, until the new Year's day comes. At that time, when Christmas was coming closer, I would get happy because it would be Christmas. But nowadays, we have to make gifts, wrap them and then put a name on them. At that time, we didn't have to do that. We would just give a present to someone. There were exchange gifts with the people who wanted to do that. Then, we would shake hands. Then we would say : " this gift for you is part of an angel ».

I remember that once somebody gave me a long big knife as an exchange gift. I was happy to get a knife that long. I kept the knife during the week and after Christmas, as we would go out hunting to get food to survive, I was happy because I thought I could use the knife for carving and making an igloo. But just after Christmas, my parents told me to give the knife back to the person who gave it to me. I did not want to do it, but as I had to, I did it.

Usually, the gifts were exchanged and after some time were returned. Theresi Ijjangiaq contrasted the presents of today with the exchange gifts of the past : «After the midnight mass, when the service was over; we used to exchange gifts but not like right now, in the old way instead. There were no presents but just exchange gifts : needles, and so on. ")

In the descriptions of Imaruittuq, Kupaaq and Ijjangiaq, Catholics from Iglulik, priests have an important role in the celebration of Christmas. The same impression emerges from Anglican testimonies. The late Tategat Akpaliapik, remembers how Christmas was celebrated in Mittimatalik (Pond Inlet, North Baffin Island) : « During Christmas time (Quviasukvik), Mikiniqsaq (Reverend J. H. Turner) would visit us in the camps. When we were sleeping, Mikiniqsaq would wake us up and we would receive presents under our pillows. Then we would have a big feast in there ». A South Baflin elder from Panniqtuuq, Saullu Nakasuk, did not mention the role of the 
Anglican missionary but again emphasized that even if gifts were small, they were crucial for the feast : «We really enjoyed the gifts even if they were not big. Sometimes, we could even get a dog for Christmas. We were thankful to have Christmas. » The gift of a dog is interesting, especially since dogs, through their names, were often very closely related to their owner (see Laugrand \& Oosten 2002). It is perceived here as a small gift.

But there were also many celebrations of Christmas remembered by the elders without the presence of any missionary.

Elise Qulaut, a Catholic from Igloolik, recalls :

When I was a little girl, on Christmas, we used to gather in a big igloo. Then I remember that there was a feast (nirivijiuaq) and dancing in Avvajja. Before the feast started, people would go out and shoot in the air. I was scared and I thought people were shooting the moon. It was Christmas or Happy New Year, I don't know. [...] Back then, Christmas was during only one day, today, it's all the week. I remember that people, mostly the closest camps, they used to gather in this qarmaq and say a prayer or the midnight mass, even when the missionary was not around.

Like Kupaaq, she emphasizes that Christmas celebrations were much shorter in the past.

Rachel Uyarasuk, an Anglican elder, grew up in the Kangiqtugaapik area (Clyde River / Mittimatalik, North Baffin Island). She remembers how the feast was celebrated in outpost camps where no ministers were around and when ulluriaqjuaq, Venus, could be seen ${ }^{13}$.

I can tell a bit about the first Christmas I remember. We all had ighuit and we were going to be celebrating Christmas. As children we were told that we were going to be celebrating Christmas. We would be told how many days it would be until Christmas. We started counting the days. We were told that we would be using our personal effects to celebrate, but it was probably because we wanted to get new things so by word of mouth. We knew we would be celebrating we started anticipating the day. In the morning I was woken up and told today is going to be Christmas so I should wake up. I put on my caribou clothing but we tried to put on our best for that day. Those that had additional clothing did this. I was woken up by my father. We went out for a bit and came back and we started shaking hands with each other because we heard that is what we had to do. Just before we went out people started rushing around and my father took a rifle and went out and shot the rifle. We heard the rifle shot and we all rushed out. I had clothing with a hat that was separate. We were told that after we went out we were going to say « hurray ». I took my hat that was not attached to my clothing and my mother gave it to me and said that was what I was going to use this to say « hurray ». Our neighbors also shot their rifles. This was going on while it was still dark. We could hear rifle shots and people would go hurray. I was holding on to my hat and then we'd go hurray. We were celebrating and were very happy. Later on that day we would go and pray and sing hymns. We went to someone else's iglu and it was cold. Even though it was light it was still winter. We all went in. The women took off their kamiik and went up on the bed platform. The bed platform was totally full, there was hardly any place to sit. There were people sitting all over the place because we were going to pray. And we prayed and there was a hymn sung. At turns out that the hymn that was sung was not a Christmas hymn, but that's the song we sang. We sang that hymn. People sat down on the floor because the iglu was so full. After this hymn was sung, somebody would read a prayer. Then another hymn would be sung. This is the first Christmas I remember. I remember the first hymn but I don't remember the other hymns that were sung. After we had sung hymns and prayed and were about to go out we all shook hands with each other. Those women who had sat on the bed platform put on their kamiik and 
we all went home. We also knew that we would be feasting. We would have a feast where we prayed, so all the meat we would be feasting on was brought there. We feasted on meat. We did not have tea. That was tunuq that was prepared as aluq, we ate quaq and ujuq. And we ate meat that we did not normally eat such as polar bear and caribou. It probably was kept for this occasion. It was a joyous time because we were celebrating. That is the first Christmas I can remember. After we had feasted we then started exchanging gifts. These were our own personal things that we exchanged. We did it when the day was over. It was already dark. We would go over to another place to exchange gifts. The gifts that were exchanged were not that big. It could be a caribou skin or a sealskin or any other personal effects. It was still a very happy occasion.

The handshakes and rifle shots constituted the start of the feast. The practice of shaking hands was probably a custom adopted from Qallunaat and played an important role in the adoption of Christianity (Laugrand 1997 ; Blaisel, Laugrand \& Oosten 1999) expressing a new relationship. People came together in an igloo, sang hymns and prayed. There was a feast on country food and gifts were exchanged. Rachel also emphasizes that the gifts were small and consisted of personal effects.

Hannah Ujaraq recalls how the feast was celebrated at Qikiqtaarjuk, near Iglulik, when there were not yet priests.

[...] when Christmas was coming, we used to build a big igloo and we had dances in there for Christmas (Quviaksukvik). At that time, we used to have a feast in this big igloo, eating caribou meat, maktaaq (whale blubber), [...] only country food because there was no white man food at that time. After having a feast, we used to have dances and say prayers. Even though there was no ministers the whole camp used to say prayers. Aloloo, Anguilainuk's son used to preach in our camp.

The building of a big igloo is a recurrent feature of Christmas celebrations. The description by Hannah conforms in many respects to the description of celebrations in Kangiqtugaapik by Rachel. In Qikiqtaarjuk there was not yet Qallunaat food available.

The late Victor Tungilik remembers how Christmas used to be celebrated in Naujaat (Repulse Bay, Hudson's Bay), among the Catholics :

During Christmas, the Catholic mission would get items from the Hudson's Bay Company. Also, the Bay Manager would climb up on top of the house and we would have a candy scramble. There would be other items in this parlaniq, scramble. It was very enjoyable. While we were at the Catholic mission, we would nugluktaq and try to get a stick into a hole. We would wrestle two at a time, and people would get prizes. The prizes were things like tea and tobacco. I was scared when somebody wanted to wrestle with me. It turned out that the person who wanted to wrestle with me wanted to do so because he wanted me to win. When I lifted that person I could not even feel his weight. It turned out that he wanted me to win a prize. I couldn't feel his weight at all when I threw him on the ground. So at first, here I was scared of him and it turned out he just wanted me to win tea or tobacco. I knew he wasn't trying hard to win at all. I was really happy to win. (Oosten \& Laugrand 1999, p. 81)

The importance of the game is quite clear in Tungilik's account. Christmas provided an opportunity for a gift to Tungilik's opponent. The game of nugluktaq, which consisted in putting a stick into a suspended hole, had sexual symbolism and implications. For instance, the Oblate priest Jean Philippe (1948, pp. 6-7) noted that before Christianity, the winner of that game would be allowed to choose a sexual 
partner among the women. Interestingly, however, the nugluktaq was still integrated into the Christmas celebrations even within the Catholic missions (see also the film Light in the Darkness by G. Mary-Rousselière).

More recently, Leah d'Argencourt (1976) related her childhood memories of Christmas celebrations in Mittimatalik « The most important part was to rejoice and celebrate the birthday of our Lord Jesus Christ. " In the weeks preceding Christmas, intensive activities focused on the trapping of Arctic foxes and the preparation of the furs. They were to be sold at the Hudson's Bay store so that presents could be bought. The men bought the presents such as special Qallumaat food and machine-made clothing. There were not yet Christmas trees according to Leah. Children should go to bed before their parents "so we would be bright and early getting up. " In Leah's account, the importance of gifts is again emphasized. Prunes and candies were found in duffel socks. Much attention is given to the ritual of handshaking between relatives but the games are not described extensively. The Christmas dinner consisted of a mix of Western and Qallunaat food : " cooked meat, and home-made beans and rice with raisins and powdered milk. "

The old style of celebrating Christmas is also still remembered by Atsainak Akeeshoo, a young woman from Iqaluit who recalls the celebration of Christmas in a hunting camp, probably in the fifties.

On Christmas morning, we would all get up very early in the morning, go to our neighbors' houses and shake everybody's hands.

Then we would wait all day for it to get dark so we could start exchanging gifts with friend and adults. We would give away needles, pieces of rope, perhaps five bullets for father, marbles, thread and even our clothing that we've been wearing for years. Each of these things became treasures, like a multi-million dollar diamond would be to rich people.

Dog teams would come to our camps bearing gifts from the other camps and we would return their visit in the same way. There was no feasting but everyone got into gift-giving as if it was going to be the last Christmas ever.

Our mothers would receive bags, donated by churches, each containing thread, thimble, needles, face cloth or towel, and a bar of face soap. It was so exciting to see all those nice-smelling things come out of the bags one by one ! Each piece was looked at and felt by all the members of the household before we went on with the rest.

If we were lucky, we would each get two pieces of candy or gum and maybe even a hard biscuit. Sometimes the RCMP used to come, by dog team, just before Christmas and they would leave a whole box of biscuits and that would be saved till Christmas night.

Christmas was not at all commercial then. We celebrated the birth of Christ and followed what the tree wise men did on Christmas night. Christmas was not for Santa Claus and toys and free candies. There was a form of a Santa Claus, a gift-giver, but we weren't taught to believe in him. I wonder how many children know about our old Christmas days and how much fun they can be without all kinds of treats in schools, big community parties for children with cartoons and free gifts from the government?

Today, the children rely on Santa Claus to make their Christmas a happy time with tinsel and gifts. We still have a gift-giving or exchanging but it doesn't get into a fever-pitch like it used to.

Why not try to bring the old spirit of Christmas back this year so we can overflow with happiness [...]. Inuit and Whites exchanging gifts and going into each others' homes to wish each other a Merry Christmas! 
Akeeshoo contrasts the old celebrations with modern feasts. There was a Santa Claus, but no one had to believe in him. Schools and government did not yet play an important part in the celebrations. Gifts were small and Christmas was not yet commercial.

The following account of Christmas well illustrates the merging of a new tradition with many old traditional practices. In Pelly Bay the missionaries were very active in organizing Christmas celebrations. From the moment he arrived in Pelly Bay, Father Van de Velde played a central role in the organization of games and competitions. The missionaries took care of the prizes that were awarded. The feast was celebrated in a big igloo, food and competitive games were the main ingredients of the celebration. Gonda describes how the feast was celebrated there in the early sixties.

The igloo about twenty five feet in diameter and fifteen feet in height, was built in a few days.

At eight o'clock Christmas Eve, one hundred and five gaily attired men, women and children assembled in the igloo for what was to be three nights and two days of games, contests, feasting and prayers.

Christmas Eve was highlighted by ancient Eskimo games and target shooting. Firing from about twenty-five feet with a .22 at strings from which dangled various prizes was quite a feat of marksmanship. A few of the contestants miraculously hit a string and thus claimed a prize. A special moment of Christmas Eve was the opening of presents. These gifts were sent to Father Van de Velde from his sister in Belgium. There was a gift for everyone. Such practical objects as cloth, wool, knives and even chess sets were the most frequent items. The Eskimos here are avid chess players.

Midnight Mass, said by Father Van de Velde, was solemn and beautiful, and somehow, having this service in an igloo seemed to bring the message that is Christmas so vividly to everyone.

After Mass, we enjoyed a lunch prepared by the mission and consisting of tea, porridge and biscuits. Candies were distributed to the children.

Christmas day was extremely cold. The thermometer read 48 degrees below zero when everyone came to the igloo at eleven-thirty for Mass. After Mass everyone went home for awhile to wait for the big Christmas dinner at three o'clock. The stew had been cooking slowly all night, and needed last-minute attention before serving up.

At three o'clock everyone converged on the igloo again bringing mugs with them. Dinner was ready. The first course was sixty frozen arctic char, previously sliced. After this was put away, the two huge kettles of caribou stew were brought in. Mugs were dipped in and soon this too disappeared. Then the steaming kettles of tea were brought in. Each family brought its kettle ; there were about twenty-five gallon kettles full of lovely, strong, hot tea. Needless to say each was drained.

After dinners there were more games, contests prizes and candy. The archery contest was performed with an ancient bow of musk-ox horn. Each contestant shot four arrows from about fifteen feet. The target was an iron ring about two inches in diameter stuck in the igloo wall.

Practically everyone had a turn, beginning with the oldest hunter. The last to try were the small children, and even the women took part in it.

In some ways the day after Christmas was the most exciting. We moved out of the igloo for some of the events. The feature event was the dog team race. Twenty-seven drivers and one hundred and sixty-two howling dogs took part; each driver was allowed six dogs. It was very cold and the course was long ; many of the Eskimos had donned their caribou parkas.

The start was furious. Many teams got tangled, momentarily, but everyone was straightened away, and soon disappeared into the gloom across Pelly Bay. The winner Otto Apsaktauk, returned over the course in about forty minutes, closely followed by Augustin Annartok. The rest 
soon returned to claim their prizes. Each was eligible. Twenty-seven prizes were placed on a table, and each in turn, according to his position in the race, stepped up to claim a prize. The prizes were good, but, of course, the big prize was winning the race, for this would be remembered, and would be the topic of conversation until the next race.

Other outdoor events included the foot races, and one marveled at the endurance of the Eskimos in being able to run in such extreme cold. One was for the young men, who ran to the top of a hill about one and one half miles from the Mission and back. The hill is about one thousand feet high and there is a huge cross on top. Every contestant was awarded a prize - with winners getting first choice.

At five o'clock it was back in the kaget for the drum dance. One seemed to be transported back to ancient times listening to the aged ladies chanting their weird songs and hearing the boom of the drum and watching the dancer gyrate to the rhythm of the beat. The dancer would emit an occasional "Iy-hi » which added more strangeness to the atmosphere. In each of the alcoves there were five or six chanters, and these ladies would sing the song of the dancer, whatever it was. It might be the Song-of-my Father or the Song-of-my-Grandfather. The drumming and chanting stopped at $10 \mathrm{p}$. m., and soon everyone went home. That is how we celebrate Christmas in Pelly Bay.

The word qaggiq refers to a feast or celebration as well as to the big igloo where a feast is celebrated. The title of Kenn Harper's book quite rightly identifies it as one of the striking features of Inuit Christmas celebrations. Country food and games played an important part in the celebrations (see also the account of Christmas celebrations in Pelly Bay by Van de Velde in Eskimo of 1948).

\section{THE TRANSFORMATIONS OF THE INUIT WINTER FEASTS}

Celebrations of Christmas were already recorded by Captains Parry and Lyon in the beginning of the $\mathrm{xIX}^{\text {th }}$ century but Inuit did not participate in them. Parry and Lyon did not allow Inuit on the ships on Sundays or Holidays. Neither did the Qallunaat participate in Inuit winter feasts. Contacts between Qallunaat and Inuit were frequent, and we may infer that Inuit observed what was going on. The Western Christmas celebrations may have influenced the winter feasts as described by Hall, Boas and Bilby. The rifle shooting, recorded in the diary of Boas, later became a striking feature of the Christmas celebrations. The ritual drinking of water, described by Hall as well as Boas, disappeared. The importance of putting on best clothing ${ }^{14}$, gifts and games continued in the Christmas celebrations. When the missionaries arrived, Christmas celebrations gradually replaced the Inuit winter feasts. In most places the traditional winter feasts disappeared rapidly. In 1899, Bilby (ANC/CMS, Reel A. 121, Journal of Julian Bilby, 1898-1899) notes that shamanism and the winter feasts in South Baffin Island were already disappearing. At that time no conversions had yet occurred. That year no winter feast was held. In 1901 he notes that the feast was still celebrated, but only by old people. In North Baffin Island the Tivajuut probably disappeared when the Inuit adopted their own version of Christianity long before the missionaries arrived. In 1921-1922 Rasmussen did not witness a Tivajuut and could only acquire scant information about it on the basis of the information provided by Ava and Ivaluardjuk. In recent years, only a few elders such as Aatuat, (born in 1894), Ujaraq (born in 1901) and Iqallijuq (born in 1905) were able to give accounts of the Tivajum based on personal experience. 
In South Baffin Island the missionaries provided Western style food and drinks to the Inuit. The disappearance of wife exchange and an increasing importance of food are the most striking changes in the transition from winter feasts to Christmas celebrations. In structural terms, food and sex are obviously related together. On the level of play, Anglican as well as Catholic missionaries had no objections to the playing of games and in fact played a leading role in organizing them and awarding prizes.

The tradition of hosting the Inuit was also adopted by other Qallumaat such as Hudson's Bay Company traders and captains of visiting ships. In several cases the Christmas dinner of the Qallunaat was kept separate from the food offered to the Inuit. Thus Fleming's account of 1913 makes clear that the Anglican missionaries had their own Western style Christmas dinner before serving food « likely to be enjoyed by our guests. Two large steaming puddings something like our Christmas pudding but not nearly so rich were served with molasses for sauce » (Harper 1983, p. 18).

The missionaries also provided small gifts to the Inuit. In this respect they continued a very old tradition. Boas and Mutch had already presented gifts at the winter feast in 1883. The role of the Qallunat in organizing the feast remained central. They provided small presents, candy scrambles, and dance and music. Thus Christmas became a feast that united Inuit and Qallunaat. Apart from the communal celebrations Qallunaat might still dine together, and Inuit have their own festive rituals, notably handshaking and gift exchange with relatives. It is emphasized that the gifts could be small, and as in the case of Kupaaq, they might even be returned after Christmas. It was the act of giving, not the gift itself that was most valorized. The idea of sharing in gifts as well as food is hence a central feature of these new rituals.

It is interesting that even religious boundaries might be crossed at Christmas. In a few accounts of Christmas, the Inuit practice of visiting people is also frequently mentioned as an important step of the preparation of the feast. Father L. Schneider (1983, p. 14) recollects that in Tavani in the 1940's, when there was still intense rivalry between Catholics and Anglicans, his Catholic Mission was completely full of Anglicans at Christmas ${ }^{15}$.

The playing of games was also a central feature in the traditional winter feasts (see Boas 1888, pp. 195-198; Oosten 2001). Games (tug-of-war, shooting matches, etc.) as well as satiric songs structured the feast. It ended with a ballgame (ajuktaqtung). Placed in a circle, all participants would try to catch the ball thrown into the air. When the ancestors, the Ullormiut, would play this game, they appeared in the sky as the Aurora Borealis. At the start of the feast the community was threatened by the tupilait, the spirits of the evil dead. At the end of the feast people played the game of their ancestors in a renewed community. In the course of the feast all tensions between spirits, people seem to have been dissolved in the games. It is remarkable that since the old Inuit winter feasts disappeared, the significance of the games has not decreased at all. They were immediately integrated into the Christmas celebrations by the missionaries (see the accounts by Peck, Van de Velde, Schneider) as well as the Inuit themselves. The description of the feast in the big igloo shows the great importance of games. Today, the extension of the celebrations over many days is to a large extent due to the games in which Inuit participate with great enthusiasm. In fact, many old games practiced during the old Inuit winter feast, such as tug-of-war, are preserved in new 
forms while new games were added and invented all the time. It seems fair to assume that on this point the ideology of the community has not changed at all in the winter celebrations. In Inuit society games always served to dissolve the tensions within the community and transform potentially dangerous and hostile relationships into competition within the games. In playing games, the community shows its capacity to deal with these tensions and to dissolve them in a general atmosphere of friendly competition. ( $c f$. the case of Victor Tungilik)

Today, elders complain that Christmas has become commercial. Leah d'Argencourt refers nostalgically to a time when shops and government did not yet meddle with the feast. From the data it also emerges that from the first interaction between Inuit and Qallunaat, as missionaries, whalers and captains of ships and Hudson's Bay Company agents played a part in the organization of the celebrations. The current commercialization and increase of scale of the feast appears to be a continuation of tradition that was always there.

The various names of the feast elucidate various aspects of it. Nirivigjuaq (« place/time of the great meal ») refers to the importance of food that has become a central issue in the feast. Many missionaries objected to this term that did not express the essence of Christmas to them. They preferred the name of Pivijuaq (« the big event ») or like Father Schneider (1983, p. 14) the name Jisusi Anivvia (" the birth of Jesus »). The terms Nuqqavik («the time when we stop») or Qitinguq (" in the middle ») reflect the contrast between the time of the feast and ordinary time. The word Quviasukvik, (" the place/time of joy ») emphasizes that Christmas is first and foremost a time of rejoicing. That also seems to have been the case with the winter feast and the Tivajuut with their great emphasis on fun and laughter or the reverse. It may be significant that in the shamanic complex the notions of joy and light were closely related.

The Inuit winter feasts transformed hostile relationships with the dead into a new alliance between the community and the inua of the game. Whereas in the traditional winter feasts the initial emphasis was on the danger of the tupilait attacking the community, the Christian tradition emphasizes the coming of light, connecting the birth of the Saviour to the return of the light. The celebration of New Year at the winter solstice is therefore highly significant. The transition to Christianity also implied a shift from sexual symbolism to alimentary symbolism. Some of the basic patterns in the Christian tradition may have looked familiar to Inuit and that may have facilitated its adoption by the Inuit. Thus Quviasukvik connects the past and the present articulating central values of Inuit and Christian traditions. *

\footnotetext{
* Manuscrit reçu en juin 2001, accepté pour publication en janvier 2002.
} 


\section{NOTES}

1. We wish to thank Theresi Ijjangiaq, Emile Imaruittuq, John MacDonald, Elise Qulaut, Hannah Ujaraq, Rachel Uyarasuk, Susan Sammons and Alexina Kublu for their co-operation and advice. Interviews with the elders were made in different context under Scientific research Licence \# 0300999N-M and $0100900 \mathrm{~N}$ obtained through the Nunavut Research Institute. We also wish to thank the FCAR and CRSH for their financial support. A preliminary version of this paper was presented at the Fourth International Congress of Arctic Social Sciences, May 16 to 20, 2001, Quebec City, Canada.

2. See Botte (1932), Jansen (1993), Meisen (1931), Meslin (1970), Miller (1993) and De Sike (1999).

3. L. Kumlien (1879) and J. W. Bilby (1923) also provide descriptions of this feast.

4. See Oosten (2001) on the role of play in the Inuit winter feasts and Blaisel \& Oosten (1997) for the exchanges in the feast.

5. See K. Rasmussen (1929, pp. 231-232 ; pp. 241-243). See also the testimonies from Aatuat and Ujaraq collected by B. Saladin d'Anglure (1989). The etymology of Tivajuut is unclear. Duncan Pryde points out that in the Western Arctic the word refers to a foot movement in a drum dance (John MacDonald, oral communication, May 2001).

6. Aagiuuk is a constellation comprising the stars Altair and Tarazed and possibly in some regions Alshain. These stars form part of the European constellation Aquila (MacDonald 1998, p. 44; Oosten \& Laugrand 2001, p. 169).

7. A good survey on Christmas celebrations, especially on the older sources is provided by Kenn Harper's book Christmas in the Big Igloo. True tales from the Canadian Arctic. For the descriptions of Christmas in the 1930 s and 40 s we rely on accounts published in various journals such as the Beaver, Eskimo, North, Inuit Monthly, Inuktitut, Inuit Today as well as oral information provided from Inuit elders.

8. See, for example, a description of a Christmas celebration in 1819-1820 by Captain Parry (1828; quoted in Harper 1984, p. 1).

9. Christmas celebrations in Labrador (see also Speck 1935) could be fruitfully compared with similar cases in Greenland described by Kleivan (1960), Nellemann (1960), Nooter (1975) and Kielsen (1996). In Nunavik, more recent Christmas celebrations have been described by Lepage (1976), Metcalfe (1978), and Dorais (2000). See also Anonymous (1981). Games emerge as particularly important. In Alaska, Christmas celebrations are also marked by games, competition and communal feasting : see Bodenhorn (1993).

10. See also Hantzsch's (1977) account.

11. L. Ducharme, "Christmas in the land of Santa Claus. Christmas in the far north ", paper preserved at the Archives Deschâtelets (Ottawa).

12. For the 1930's and 1940's period, other accounts of Christmas can be found in the Oblate missionary archives : see " Christmas in Iglulik » (LCB 421 C56R 4), "Noël Esquimau » (HEB 3335 L93C 19) and « Noël fiévreux » (HEB 3335 L93C 20).

13. The year she moved to Aggu Bay she could no longer see it at Christmas : " I thought it might be a sign that world would end » (MacDonald 1998, p. 93).

14. See, for example, "Noël Esquimau » (HEB 3335 L93C 19). The Oblate missionary observes that the first thing visiting people do when they used to gather for Christmas, was to buy new clothing for all of them including children at the Hudson's Bay Company post.

15. See also « Noël Esquimau » (HEB 3335 L93C 19). The Oblate missionary observes that Catholics as well as Anglican assisted together to the Midnight Mass.

\section{REFERENCES}

AKeeshoO, Atsainak, 1974. - «Christmas in a Hunting Camp », Inukshuk, 23, Dec., p. 8. Anonymous, 1981. — « Les fêtes de Noël au Nouveau Québec », Inuktitut, pp. 28-33.

BEN-Dor, Shmuel, 1969. — «The "Naluyuks" of Northern Labrador ; A Mechanism of Social Control ", in : H. Halpert \& G. M. Story (eds.), Christmas Mumming in Newfoundland, University of Toronto Press, pp. 76-103, Toronto. 
BERnIER, Joseph-Elzear, 1909. - Report on the Dominion Government Expedition to Arctic Islands and the Hudson Strait on Board the C.G.S. "Arctic " 1906-1907, King's Printer, Ottawa.

- n.d. - Report on the Dominion Government Expedition to Arctic Islands and the Hudson Strait on Board the C.G.S. "Arctic " 1910, King's Printer, Ottawa.

BILBY, Julian W., 1923. - Among the Unknown Eskimo, Seeley Service and Co Ltd, London.

BLAisf: , Xavier \& Jarich G. Oosten, 1997. — « La logique des échanges des fêtes d'hiver inuit », Anthropologie et Sociétés, 21 (2-3), pp. 19-44.

Blaisel, Xavier, Frédéric Laugrand \& Jarich G. Oosten, 1999. — «Shamans and Leaders : Parousial Movements Among the Inuit of Northeast Canada », Numen, 46, pp. 370-411.

Boss, Franz, 1964 [1888]. - The Central Eskimo, University of Nebraska Press, Lincoln.

—, 1901. - The Eskimo of Baffin Land and Hudson Bay, Bulletin of the American Museum of Natural History, 15 (1 and 2), New York.

Bodenhorn, B., 1993. - « Christmas Present : Christmas Public », in : D. Miller (ed.), Unwrapping Christmas, Clarendon Press, Oxford, pp. 193-216.

Boisclatr, J. B., 1950. - «Christmas in the far North », Eskimo, 19, pp. 13-14.

Boтte, Bernard, 1932. - Les Origines de la Noël et de l'Épiphanie. Étude historique, Louvain.

Clabaut, Armand, 1932. - « Noël chez les Esquimaux », L'Apostolat, pp. 118-119.

D'Argencourt, Leah, 1976. - «Christmas at Aulatsivik », Inuit Today, 5 (11), Dec., pp. 2840.

DE SIKE, Yvonne, 1999. - Fêtes et croyances populaires en Europe, Bordas, Paris.

DoraIs, Louis-Jacques, 2000. — « Le temps des Fêtes à Quaqtaq ", Études Imuit Studies, 24 (2), pp. 139-150.

Egede, Hans, 1986. - Die Heiden im Eis. Als Forscher und Missionar in Grönland 1721-1736, Thienemann, Stuttgart-Wien.

FINNIE, Richard, 1940. - Lure of the North, David McKay Company, Philadelphia.

Fleming, Archibald Lang, 1956. - Archibald the Arctic, Appleton-Century-Crofts, Inc., New York.

Gonda, Frank S., 1963. — «Christmas in the Big Igloo ", North, x (6), Nov.-Dec., pp. 28-29.

HaLl, Charles Francis, 1864. - Life with the Esquimaux, vol. 1 and 2, Sampson, Low, Son, and Marston, London.

Halpert, H. \& G. M. Story (eds.), 1969. - Christmas Mumming in Newfoundland, University of Toronto Press, Toronto.

Hantzsch, Bernhard Adolph, 1977. - My Life Among the Eskimos: The Baffinland Journals of Bernhard Adolph Hantzsch 1909-1911, University of Saskatchewan, Saskatoon.

Harper, Kenn, 1983. - Christmas in the Big Igloo. True Tales from the Canadian Arctic, Outcrop, The Northern Publishers, Yellowknife.

IPELLIE, Alooktook, 1972. - « Community Christmas », North, XIX (6), Nov--Dec., pp. 24-27.

—, 1974. - « Christmas is for Everyone », Imuit Monthly, III (9), Nov.-Dec., pp. 36-39.

JANSEN, L., 1993 - Nicolaas, de duivel en de doden, Ambo.

Kielsen, Lene, 1996. - « Mitaartut: An Inuit winter festival in Greenland », Études Imuit Studies, 20 (1), pp. 123-129. 
KLeivan, Inge, 1960. - «Mitârtut, vestiges of the Eskimo sea-woman cult in West Greenland », Med. Om Grönland, Bd 161 (5), pp. 1-30.

Kumlien, Ludvig, 1879. - " Contributions to the Natural History of Arctic America ", Bulletin of the United States National Museum, 15, Washington.

LAUGRAND, Frédéric, 1997. - Siqqitiqpuq : conversion et réception du christianisme par les Inuit de l'Arctique de l'Est canadien (1890-1940), Université Laval, Département d'anthropologie, Québec.

Laugrand, Frédéric \& Jarich Oosten, 2002, — « Canicide and Healing. The Position of the dog in the Inuit Cultures of the Canadian Arctic ", Anthropos, 97 (1), pp. 89-105.

Lepage, Eva, 1976. - « Christmas Time in Sugluk », Inuit Today, v (11), Dec., pp. 44-47.

Lévi-Strauss, Claude, 1952. — « Le Père Noël supplicié », Les Temps Modernes, pp. 15781590.

Lyon, George Francis, 1824. - The private journal of Captain G.F. Lyon, of H.M.S. Hecla, during the recent voyage of discovery under Captain Parry, John Murray, London.

Macdonald, John, 1998. - The Arctic Sky: Imuit Astronomy, Star Lore, and Legend, Royal Ontario Museum, Ottawa.

Mary-Rousselière, Guy, 1956. - «Christmas Igloo », The Beaver, Winter, pp. 4-5.

Mersen, K., 1931. - Nikolauskult und Nikolausbrauch im Abendland, Düsseldorf.

Mrstın, Michel, 1970. - La fête des Kalendes de janvier dans l'Empire romain, Latomus, 115, Bruxelles.

Metcalfe, Sam, 1978. — «Christmas Time in Northern Labrador », Inuktitut, Winter, pp. 1826.

Miller, Daniel (ed.), 1993. - Unwrapping Christmas, Clarendon Press, Oxford.

MüLler-Wille, Ludger, 1998. - Franz Boas among the Inuit of Baffin Island 1883-1884. Journals and Letters, University of Toronto Press, Toronto.

Munn, Henry Toke, 1932. - Prairie Trails and Arctic By-Ways, Hurst and Blackett, Ltd, London.

Nellemann, Georg, 1960. — " Mitârneq, a West Greenland winter ceremony ", Folk, 2, pp. 99 113.

NoотеR, Gert, 1975. - « Mitârtut, winter feast in Greenland », Objets et Mondes, xv (2), été, pp. 159-168.

Oosten, Jarich, 2001. — « Ritual Play at an Inuit Winterfeast », North Atlantic Studies, 4 (1 and 2), pp. 17-24.

Oosten, Jarich \& Frédéric Laugrand (eds.), 1999. - The Transition to Christianity. Inuit Perspectives on the XXth Century, vol. 1, Nunavut Arctic College/Nortext, Iqaluit.

—, 2001. - Travelling and Surviving on Our Land. Inuit Perspectives on the XXth Century, vol. 2, Nunavut Arctic College/Nortext, Iqaluit.

PARry, William Edward, 1828. - Journals of the First, Second and Third Voyages for the Discovery of a North-West Passage, John Murray, London.

Philippe, Jean, 1948. — « Eskimo Psychology. Marriage », Eskimo, 10, pp. 2-7, 14.

-, 1952. — «Christmas », Eskimo, 27, pp. 2-4.

—, 1956. — « Noël chez les Esquimaux », Eskimo, Dec., 6-7.

Rasmussen, Knud, 1929. - Intellectual Culture of the Iglulik Eskimos. Report of the Fifth Thule Expedition 1921-1924, vol. vII (1), Copenhagen. 
Richling, Barnett, 1983. - «Labrador Naluyuk: The Transformation of an Aboriginal Ritual Complex in a Post-Contact Setting », in : N. Ross Crumrine \& M. Halpin (eds.), The Power of Symbols: Mask and Masquerade in the Americas, University of British Columbia, Vancouver, pp. 21-29.

Saladin d'Anglure, Bernard, 1989. — « La part du chamane ou le communisme sexuel inuit dans l'Arctique central canadien ", Journal de la Société des Américanistes, Lxxv, pp. 133171.

Schneider, Lucien, 1983. — « La vie à Tavani... il y a 40 ans », Eskimo, 25, pp. 10-18.

SPECK, Frank, G., 1935. - « Labrador Eskimo Mask and Clown », The General Magazine and Historical Chronicles, 37 (2), pp. 159-173.

Stevenson, Alex, 1965. - «Quviasukvik. The Time for Rejoicing, Arctic Christmas Thirty years Ago », North, XII (6), Nov.-Dec., pp. 28-31.

Szala-MeneoK, Karen, 1994. - « Christmas Janneying and Easter Drinking : symbolic inversion, contingency, and ritual time in coastal Labrador », Arctic Anthropology, 31 (1), pp. 103-116.

VAn de Velde, Franz, 1948. — «Christmas near the Magnetic Pole », Eskimo, 11, pp. 2-4. 